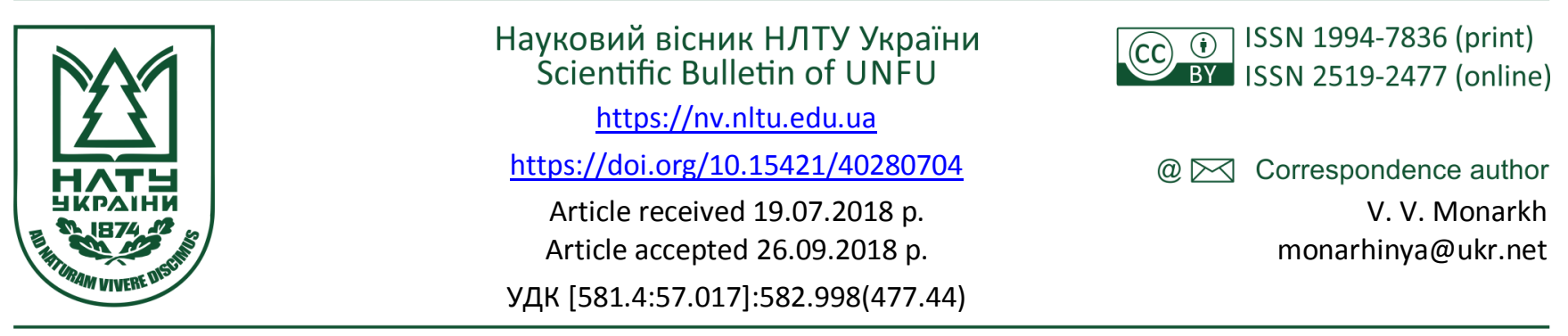

V. M. Cherniak', V. M. Prokopchuk', V. V. Monarkh ${ }^{2}$

${ }^{l}$ Ternopil Regional Communal Institute of Post-diploma Pedagogical Education, Ternopil, Ukraine

${ }^{2}$ Vinnytsia National Agrarian University, Vinnytsia, Ukraine

\title{
SOME PROSPECTS OF GROWING AND USE OF CHINA ASTER FOR SPACE GREENING IN PODILLIA ZONE
}

\begin{abstract}
Annual aster, also called China aster (Callistepsus chinensis (L.) Nees) is one of the priority ornamental flower plants for the introduction both in Ukraine and throughout the world. Domestic and foreign scientists are diverse in the study of this plant. Most of the works published during the last decades are devoted to the study and search for the most favorable agrotechnical techniques for aster cultivation under different conditions. The research was being carried out during 2016-2017 on the territory of the Bio-stationary of Vinnytsia National Agrarian University with partial subsequent data processing at Bila Tserkva National Agrarian University. The purpose of the study was to identify the most adapted and resistant samples among the collection cultivars of China aster for their further breeding and greening of various objects of Vinnytsia region. The methods of field and laboratory research were applied in accordance with the basic methodological requirements. The prospects of growing cultivars of China aster (Callistepsus chinensis) in the green space of Vinnytsia region were analyzed. The demand for new cultivars of different groups of annual aster in ornamental gardening and the need to develop decorative cultivars resistant to diseases and adapted to the environment was proved. For the first time, biomorphological features of Chinese asters (Callistepsus chinensis), methods of reproduction and the most promising cultivars for their growing under conditions of Vinnytsia region and their further use in landscaping of various objects were investigated. A collection of cultivars of different groups of Chinese aster on the territory of the collection site of Vinnytsia National Agrarian University was produced and unified. Due to high ornamental qualities, economic and biological qualities of the studied cultivars, all of them are evaluated as well adapted to the edaphic and climatic conditions of Podillya and they are recommended as objects intended for the replenishment of the assortment of plants for greening, collection and exhibition funds as well as breeding activities. A diversity of colours and forms of inflorescence, various shapes and height of the bush enable to use China aster widely in the single linear plantations, group plantations, for the arrangement of mixborders and plant beds, on the rocky landscapes and borders, to create groups and flower beds.
\end{abstract}

Keywords: Callistepsus chinensis; biomorphological features; introduction; flowering period; decorative qualities; cultivars.

Introduction. Annual aster, also called China aster (Callistepsus chinensis (L.) Nees) is one of the priority ornamental flower plants for the introduction both in Ukraine and throughout the world (Anonymous, 2014; Bhargav et al., 2016; Chaitra, \& Patil, 2007; Chowdhuri et al., 2016; Dilta, Gupta, \& Sharma, 2007).

China aster belongs to the Asteraceae family, the subfamily Tubuliflorae, the genus Callistephus Cass., which includes over 40 groups or cultivar types. Under natural conditions, C. chinensis is common in the Eastern and Northern China, Japan, southern Far East, Russia and the northern part of the Korean Peninsula. It grows in natural conditions, mainly in the mountains on the rocky slopes and stony scatterings. Today, the world collection includes more than 4000 cultivars (Levandovska \& Oleshko, 2014).

For the first time, China aster seed was imported to Europe from China in 1728. France is considered to be the first breeding center for China aster, where a cultivar with the double inflorescence was produced in 1750. Over the past decade, French breeders have produced a magnificent Riviera Garden Group, which belongs to Holchsta variety type, cultivars of Duchess variety type as well as a series of cultivars of Miledi variety type (Sytov, 1991).

In 1752, this plant was brought to England from France. By the end of the XVIII century. English breeders had produced a large number of cultivars with blue, purple and pink calathiums (Tavlinova, 2001).

From the $19^{\text {th }}$ century, China Aster Breeding Center moved to Germany. And it was the German gardeners who played a crucial role in the formation of the world assortment of China aster. It should be noted that among 44 variety types that are known today, 20 of them have been produced by the German breeders, e.g. Straw Pen, Comet, Queen of the Market, Royal Dwarfs, Liliput, Petio and

Інформація про авторів:

Черняк Володимир Максимович, д-р біол. наук, професор, завідувач кафедри змісту і методик навчальних предметів.

Email: monarhinya@ukr.net

Прокопчук Валентина Мар'янівна, канд. біол. наук, доцент, кафедра садово-паркового господарства, садівництва та виноградарства. Email: monarhinya@ukr.net

Монарх Вероніка Валентинівна, канд. с.-г. наук, ст. викладач, кафедра садово-паркового господарства, садівництва та виноградарства. Email: monarhinya@ukr.net; https://orcid.org/0000-0002-4473-7683

Цитування за ДСТУ: Черняк В. М., Прокопчук В. М., Монарх В. B. Some prospects of growing and use of china aster for space greening in Podillia zone. Науковий вісник НЛтУ України. 2018, т. 28, № 7. С. 22-26.

Citation APA: Cherniak, V. M., Prokopchuk, V. M., \& Monarkh, V. V. (2018). Some prospects of growing and use of china aster for space greening in Podillia zone. Scientific Bulletin of UNFU, 28(7), 22-26. https://doi.org/10.15421/40280704 
others. As an industrial crop, this plant has become widespread only since 1980 (Levandovska \& Oleshko, 2014).

In the US, the breeding of China aster was initiated in the late $19^{\text {th }}$ and early $20^{\text {th }}$ centuries. Cultivars of Princess variety type was first produced by the American gardeners in 1949 (Levandovska \& Oleshko, 2014).

In 1975, a group of dwarf cultivars of Pinocchio variety type was developed and distributed in Holland. The originators from Sweden have replenished the world's assortment with the new variety type called Madelin. 18 promising cultivars for industrial cultivation were obtained as a result of a thorough and long-term work of Polish breeders. In 1923, for the first time, Russian scholars started breeding of annual aster. Moldova has been engaged in the breeding of China aster since 1967 (Levandovska \& Oleshko, 2014).

By the beginning of the second half of the $20^{\text {th }}$ century, in Ukraine, the cultivars of mainly foreign origin had been cultivated. Although the breeding work with China aster began in the country not so long time ago, Ukrainian breeders have already produced a number of new cultivars that are not inferior to the world standards and are more adapted to the edapho-climatic conditions of Ukraine (Levandovska \& Oleshko, 2014).

The first researches on the breeding of this plant were initiated in the National Botanical Garden named after M. M. Hryshko of the National Academy of Sciences of Ukraine, where the largest collection of China aster is gathered and comprised of 164 cultivars ('Aniuotochka', 'Veresneva', 'Zhemchug', 'Leleka', 'Kiev waltz', 'Varia' and many others) belonging to 27 variety types.

Domestic and foreign scientists are diverse in the study of this plant. Most of the works published during the last decades are devoted to the study and search for the most favorable agrotechnical techniques for aster cultivation under different conditions (Khangjarakpam et al., 2014; Munikrishnappa et al., 2013; Navalinskien, Samuitien, Jomantiene, 2005; Pandey \& Rao, 2014; Patil, 1990; Pratiksha et al., 2017).

The scientists argue that the data, which presents the features of growth and development of China aster, the level of productivity of various cultivars, their respond to a specific set of weather and climatic conditions, can be rarely found in the literature, and there are no studies on these issues under the conditions of Podillia region. Therefore, they are of great relevance for the effective breeding of cultivars resistant to specific natural conditions of cultivation, preservation of thei gene pool and expansion of the assortment of ornamental flower plants in modern landscaping (Doddagoudar, Vyakarnahal \& Shekargouda, 2004; Levandovska, 2010; Rai \& Chaudhary, 2016; Reddy \& Sulladmath, 1983; Vashchenko, Lange \& Merkulov, 1982).

Thanks to simplicity of the growing conditions, diversity of colors in cultivars, unusual form and duration of plant flowering, asters are widely grown on the private plots, in the parks, squares, and in pot culture and they are actively used in phyto- and flora interior design (Alekseeva, 2006; Alekseeva, Cherniak \& Levandovska, 2008; Kozevnikov, 2002).

The study of the history of origin, assortment of this plant is of great significance for further introduction and replenishment of the collection fund of China aster ( C. chinensis) in the territory of Vinnytsia region.

Materials and methods. The research was carried out during 2016-2017 on the territory of the Bio-stationary of
Vinnytsia National Agrarian University with partial subsequent data processing at Bila Tserkva National Agrarian University.

The object of the research was the species of China aster with its cultivars that are the most ornamental and resistant to diseases and pests under conditions of Vinnytsia region and the bio-stationary of VNAU.

The aim of the study was to identify the most adapted and resistant samples among the collection cultivars of China aster for their further breeding and greening of various objects of Vinnytsia region.

The methods of field and laboratory research were applied in accordance with the basic methodological requirements by B. A. Dospekhov. The scheme of sowing was small site and drilled, site location was randomized (Vashchenko, Lange \& Merkulov, 1982).

Results. The terms and sequence of flowering depend on the biological characteristics of cultivars and climatic conditions (Zosiamliana, Reddy \& Rymbai, 2013). Having analyzed the terms of sowing, germination and flowering of the studied cultivars of China aster, a calendar of plant flowering was formed (Figure 1).

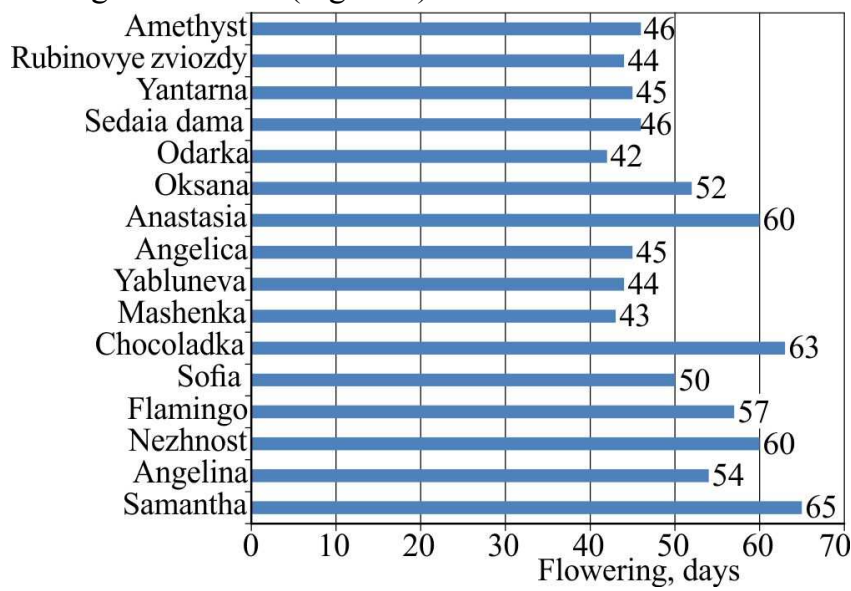

Fig. 1. Duration of flowing of the studied cultivars of China aster

Analysis of duration of flowering have shown that on average in 2016-2017, 'Odarka' cultivar has the minimum index of 42 days, while 'Chocolate' and 'Samantha' had the maximum indices of 63 and 65 days, respectively.

By the duration of the interphase period of vegetation from the beginning of flowering to the complete loss of ornamentality, the cultivars of aster were divided into 3 groups, namely early, middle and late. 'Amethyst' cultivar is considered to be early with the duration of the period of "germination - mass flowering" lasting for 120-130 days. Such cultivars as 'Odarka', 'Oksana', 'Anastasia', 'Angelica', 'Yabluneva', 'Sedaia dama', 'Samantha' have a middle interphase period of 131-145 days. Such cultivars as 'Mashenka', 'Chocoladka', 'Sofia', 'Flamingo', 'Nezhnost' and 'Angelina' were attributed to the group of the late interphase period (146-160 days).

The vast majority of the studied cultivars of annual asters had a flowering period similar to the standard one, which indicates favorable weather conditions as well as properly selected and applied cropping practices (seeding, transplanting, nutrition, watering, weed and pest control).

In the course of the conducted research, it was established that under conditions of the bio-stationary of VNAU the introduced cultivars of the annual aster ( $C$. shenensis) showed high fruit bearing results. This indicator varies within 2.0-5.0 g/bush. The results are presented in Table 1. 
Table 1. Seed productivity of China aster cultivars (2016-2017)

\begin{tabular}{|c|c|c|c|}
\hline $\begin{array}{c}\text { Name of the } \\
\text { cultivar }\end{array}$ & $\begin{array}{c}\text { Seed producti- } \\
\text { vity, g/bush }\end{array}$ & $\begin{array}{c}\text { Name of the } \\
\text { cultivar }\end{array}$ & $\begin{array}{c}\text { Seed producti- } \\
\text { vity, g/bush }\end{array}$ \\
\hline Amethyst & 5.0 & Yabluneva & 3.5 \\
\hline $\begin{array}{c}\text { Rubinovye } \\
\text { zviozdy }\end{array}$ & 3.5 & Mashenka & 2.0 \\
\hline Yantarna & 3.0 & Chocoladka & 3.5 \\
\hline Sedaia dama & 3.5 & Sofia & 3.0 \\
\hline Odarka & 4.5 & Flamingo & 3.5 \\
\hline Oksana & 2.5 & Nezhnost & 3.0 \\
\hline Anastasia & 2.0 & Angelina & 3.0 \\
\hline Angelica & 2.5 & Samantha & 2.0 \\
\hline
\end{tabular}

Cultivars produced by the Institute of Horticulture of NAAN, namely 'Amethyst' and 'Odarka', had relatively high yields, in particular $5.0 \mathrm{~g} /$ bush and $4.5 \mathrm{~g} / \mathrm{bush}$, respectively. The lowest seed yield was found in such cultivars as 'Mashenka' (2 g/bush), 'Samantha' (2 g/bush), and 'Anastasia' ( $2 \mathrm{~g} /$ bush).

According to these studies, in 2017, seed yield indices were significantly lower than those in 2016, but seed yields appeared to be higher and variation coefficient was lower in 2017. This indicates a weak direct correlation of the level of ornamentality and productivity of China aster plants, since the results of the studies are reliable, and the variation coefficient is rather insignificant.

According to the research results on the effect of mineral fertilizers on the height of annual asters, it was found that all of 16 varieties experienced plant elongation on the background of mineral fertilization, compared to the standard. The highest values were obtained at the rate of mineral fertilizers of $6.0 \mathrm{~g} / \mathrm{m}^{2}$. The increase in the bush height of the studied cultivars ranged from $4 \%$ ('Angelina' cultivar) to $60 \%$ ('Oksana' cultivar) (Figure 2).
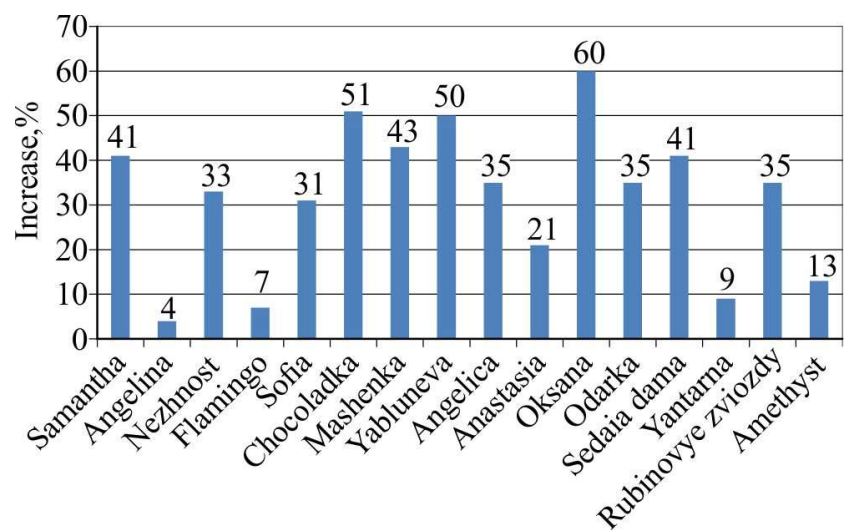

Fig. 2. The effect of mineral fertilizers on the plant height of Chinese aster (C. shenensis)

From the point of view of the culture application in the flower design, where variability in height within the cultivar is unacceptable, the established response to the introduction of mineral fertilizers is negative. Early cultivar 'Amethyst' responded to increased rates of fertilizers by $5.1 \mathrm{~cm}$ increase in height within the experiment; mid cultivars, in particular 'Odarka', 'Oksana', 'Anastasia', 'Angelica', 'Yabluneva', 'Samantha', on average, responded by $11.1 \mathrm{~cm}$ increase in height, and late cultivars 'Chocoladka', 'Sofia', 'Flamingo', 'Nezhnost', 'Angelina', 'Yantarna' responded by $12 \mathrm{~cm}$ increase in height, on average. The highest respond to the rate of mineral fertilizers was observed in cultivars 'Oksana', 'Chocoladka' and 'Yabluneva', in which the bush height increased by $60 \%, 51 \%$ and $50 \%$, respectively.
Sowing of seeds under conditions that are less favorable than those provided by the standard enables to get additional characteristics of seed quality.

Discussion. Considering the environmental aspects of growing annual asters in the green areas of Podillia zone, in particular in the collection site and the entire territory of Vinnytsia National Agrarian University, the following points should be noted:

1. Development of the garden and park compositions requires proper selection of the plant material taking into account the age and seasonal dynamics as well as ecological expediency.

2. Species characteristics are as important as individual morpho-biological and ornamental features of plants, which enhance ornamental expressiveness of other elements of artistic compositions. China aster can be perfectly combined with deciduous and coniferous flower and ornamental plants that represent different life forms (trees, shrubs, herbs).

3. The use of China aster is not limited to the open ground, since this plant is often used for indoor decoration and creation of floral compositions.

4. According to our studies and previous research results, growing of China aster under conditions of large cities, on the territories of industrial buildings are of great relevance. A great share of flower plants badly withstands urban pollution, so, from the environmental point of view, it is rather problematic to choose plants that are resistant to adverse environmental factors. However, such China aster cultivars as 'Nezhnost', 'Angelina', 'Chokoladka', 'Angelica', 'Yantarna', 'Odarka' are resistant to dust and they do not require special growing conditions, which is extremely important when choosing a range of floral products for the greening of urban areas.

Cultivar diversity of the studied species enables to use plants for different purposes, e.g. to design flower beds, edges, China asters can also be planted in the shadow areas, which often remain completely undecorated with flowers or sometimes decorated with unsuitable plants because of our conditions; creation of rocky gardens, where they are planted alone or in groups between stones, they look excellent on their gray background; group plantations of China aster can be intended for gardens and parks; wonderful China asters in border and alley plantations near the walls and foundation of buildings; spectacular in mixborders; like solitaries in the light lawns, bordered by dark leaves of bushes; in hedges, the aster is ornamental both in the front and in the background, and they are also used as houseplants to create a special interior.

Generalized guidelines on the use of different species for space greening taking into account their bio-morphological features are given in Table 2 .

From the practical point of view, all the species investigated are of great interest as potentially valuable objects for the replenishment of assortment of ornamental plants in Ukraine and they are considered to be promising for improving the condition of parks, gardens and gardens.

Conclusion. Due to high ornamental qualities, economic and biological qualities of the studied cultivars, all of them are evaluated as well adapted to the edaphic and climatic conditions of Podillia and they are recommended as objects intended for the replenishment of the assortment of plants for greening, collection and exhibition funds as well as breeding activities. 
Table 2. Biomorphological features and guidelines on the use of ornamental cultivars of the genus C. chinensis

\begin{tabular}{|c|c|c|c|c|l|}
\hline \multirow{2}{*}{ Name of variety } & \multirow{2}{*}{ Variety type } & \multicolumn{2}{|c|}{ Plant size } & Duration of flo- & \\
\cline { 3 - 4 } & weight & width & Gering, days & \\
\hline Samantha & Tubular & $45-50$ & $20-25$ & 65 & Borders, flower beds, in vases, rocky gardens \\
\hline Angelina & Tubular & $60-65$ & $20-25$ & 54 & Solitaires, plant beds, retaining walls, aster flower beds \\
\hline Nezhnost & Artistic & $60-70$ & $45-50$ & 60 & Mixborders, groups, land tracts \\
\hline Flamingo & Artistic & $45-50$ & $20-25$ & 57 & Borders, flower beds, in vases, rocky gardens \\
\hline Sofia & Artistic & $60-65$ & $30-35$ & 50 & Solitaires, plant beds, retaining walls \\
\hline Shocoldka & Artistic & $65-70$ & $35-40$ & 63 & Mixborders, groups, flower arrangement \\
\hline Mashenka & Triumph & $35-40$ & $30-35$ & 43 & $\begin{array}{l}\text { Borders, flower beds, modular flower beds, rocky gar- } \\
\text { dens }\end{array}$ \\
\hline Yabluneva & Similar to peony & $45-50$ & $30-35$ & 44 & Borders, flower beds, in containers, rocky gardens \\
\hline Angelica & Similar to peony & $70-75$ & $35-40$ & 45 & Mixborders, groups, near the walls of buildings \\
\hline Anastacia & Similar to peony & $60-65$ & $30-35$ & 60 & Solitaires, plant beds, retaining walls \\
\hline Oksana & Similar to peony & $60-65$ & $30-35$ & 52 & Solitaires, plant beds, retaining walls, flower beds \\
\hline Odarka & Similar to peony & $65-70$ & $30-40$ & 42 & Mixborders, groups, modular flower beds \\
\hline Sedaia dama & Duches & $65-75$ & $45-55$ & 46 & Solitaires, plant beds, retaining walls, flower beds \\
\hline Yantarna & American bush & $75-80$ & $35-40$ & 45 & Mixborders, groups, land tracts \\
\hline Rubinovye zviozdy & Unique colon-like & $60-65$ & $30-35$ & 44 & $\begin{array}{l}\text { Solitaires, plant beds, retaining walls, modular flower } \\
\text { beds }\end{array}$ \\
\hline Amethyst & Valderzes & $40-45$ & $35-45$ & 46 & Borders, flower beds, for arrangement, stony gardens \\
\hline
\end{tabular}

A diversity of colors and forms of inflorescence, various shapes and height of the bush enable to use China aster widely in the single linear plantations, group plantations, for the arrangement of mixborders and plant beds, on the rocky landscapes and borders, to create groups and flower beds.

\section{Перелік використаних джерел}

Alekseeva, N. M. (2006). Odnorichni aistry firmy Benari. Kvity Ukrainy, 5, 9-13. [In Ukrainian].

Alekseeva, N. M., Cherniak, V. M., \& Levandovska, S. M. (2008). Aistry. Biolohichni osoblyvosti vyroshchuvannia. Vykorystannia. Sorty. Ternopil: Vyd-vo "Navch. knyha - Bohdan". 160 p. [In Ukrainian].

Anonymous. (2014). Statistical data on horticultural crops in Karnataka State. Department of Horticulture, Lalbagh, (pp. 37-38). Bengaluru.

Bhargav, V., Sharma, B. P., Dilta, B. S., Gupta, Y. C., \& Negi, N. (2016). Effect of different plant spacings and cultivars on growth, flowering and seed production of China aster [Callistephus chinensis (L.) Nees]. Research in Environment and Life Science, 9(8), 970-972.

Chaitra, R., \& Patil, V. S. (2007). Integrated nutrient management studies in China aster (Callistephus chinensis Nees) cv. Kamini. Karnataka Journal of Agricultural Sciences, 20(3), 689-690.

Chowdhuri, T. K., Rout, B., Sadhukhan R., \& Mondal, T. (2016). Performance evaluation of different varieties of China aster (Callistephus Chinensis L. Ness) in sub-tropical belt of West Bengal. International Journal of Pharmaceutical Science Invention, 5(8), 15-18.

Dilta, B. S., Gupta, Y. C., \& Sharma, P. (2007). Effect of different planting dates on performance of China aster (Callistephus chinensis Nees) varieties. Asian Journal of Horticulture, 2(2), 245-248.

Doddagoudar, S. R., Vyakarnahal, B. S., \& Shekargouda, M. (2004). Effect of mother plant nutrition and chemical spray on seed germination and seedling vigour of China aster cv. Kamini. Karnataka Journal of Agriculture Sciences, 17(4), 701-704.

Khangjarakpam, G., Kumar, R., Seetharamu, G. K., Rao, T. M., Dhananjaya, M. V., Venugopalan, R., \& Padmini, K. (2014). Seed setting studies in China aster [Callistephus chinensis (L.) Nees]. Progressive Agriculture, 14(1), 189-191.

Kozevnikov, V. I. (2002). Ekologicheskoe obosnovanie razmesheniya semenovodstva astry odnoletnej (Sorta Callistephus chinensis Nees) v Stavropolskom krae. Abstract of Doctoral Dissertation for Agricultural Sciences (06.03.01 - Forest Crops and Phytomelioration). Moscow. 28 p. [In Russian].

Levandovska, S. M. (2010). Sorty Callistephus chinensis (L) Nees: Morfolohiia, biolohiia rozvytku ta kultyvuvannia na sadovo-parkovakh obiektakh zakhidnoho Podillia. Abstract of Doctoral Disserta- tion for Biology Sciences (06.03.01 - Forest Crops and Phytomelioration) Svitlana Mykolaivna Levandovska. Kyev: NUBiP. 21 p. [In Ukrainian].

Levandovska, S. M., \& Oleshko, O. H. (2014). Istoriia introduktsii ta suchasnyi svitovyi sortyment aistry odnorichnoi (Callistephus Chinensis (L.) Ness). Scientific Bulletin of UNFU, 24(4), 91-95. [In Ukrainian].

Munikrishnappa, P. M., Patil, A. A., Patil, V. S., Patil, B. N., Channappagoudar, B. B., \& Alloli, T. B. (2013). Studies on the growth and yield parameters of different genotypes of China aster (Callistephus chinensis Nees). Karnataka Journal Agricultural Sciences, 26(1), 107-110.

Navalinskien, M., Samuitien, M., \& Jomantiene, R., (2005). Molecular detection and characterization of phytoplasma infecting Callistephus chinensis plants in Lithuania. Phytopathologia Polonica, 35, 109-112.

Pandey, N., \& Rao, V. K. (2014). Influence of planting geometry on performance of China aster genotypes under mid hill conditions of Uttarakhand. Journal of Hill Agriculture, 5(2), 139-143.

Patil, S. S. D. (1990). Heterosis and combining ability studies in China aster [Callistephus chinensis (L.) Nees]. Ph.D. thesis submitted to Mahatma Phule Agricultural University, Rahuri.

Pratiksha, K., Kumar, R., Rao, T. M., Bharathi, T. U., Dhananjaya, M. V., \& Bhargav, V. (2017). Evaluation of China aster [Callistephus chinensis (L.) Nees] F1 hybrids and parents for growth, flower quality, yield and postharvest life. International Journal of Current Microbiology and Applied Science, 6(8), 1543-1549. https://doi.org/10.20546/ijcmas.2018.702.200

Rai, T. S., \& Chaudhary, S. V. S. (2016). Evaluation of China aster (Callistephus chinensis Nees) cultivars under mid-hill conditions of Himachal Pradesh. The Bioscan, 11(4), 2367-2370.

Reddy, Y. T. N., \& Sulladmath, U. V. (1983). Effect of growth regulators on growth and flowering of China aster (Callistephus chinensis (L.) Ness.). South Indian Journal of Horticulture, 31, 95-98.

Sytov, E. A. (1991). Vliyanie uslovij zon vyrashivaniya semyan astry odnoletnij na ih sortovye kachestva. Abstract of Doctoral Dissertation for Agricultural Sciences (06.03.03 - Silvics and Forestry). Moscow. 31 p. [In Russian].

Tavlinova, G. K. (2001). Astry. Saint Petersburg. 224 p. [In Russian].

Vashchenko, I. M., Lange, K. P., \& Merkulov, M. P. (1982). Praktikum po osnovam selskogo hozyajstva: Uchebnoe posobie dlya studentov biol. spec. ped. in-tov, (pp. 102-104). Moscow: Prosveshenie. 360 p. [In Russian].

Zosiamliana, J. H., Reddy, G. S. N., \& Rymbai, H. (2013). Study on the performance of some varieties of China aster (Callistephus chinensis Ness) in Andhra Pradesh. Progressive Horticulture, 45(2), 312-316. 


\section{ПЕРСПЕКТИВНІСТЬ ВИРОЩУВАННЯ ТА ВИКОРИСТАННЯ CALLISTEPHUS CHINENSIS В} ОЗЕЛЕНЕННІ ЗОНИ ПОДІЛЛЯ

Однією із пріоритетних в інтродукційній роботі квітково-декоративних рослин, як в Україні, так і в усьому світі, є айстра однорічна, або калістефус китайський (Callistepsus chinensis (L.) Nees). Вітчизняні та зарубіжні вчені різнопланово вивчають цю рослину. Більшість праць, що опубліковані впродовж останніх десятиріч, присвячені вивченню та пошуку найсприятливіших агротехнічних прийомів для вирощування айстри в різних умовах. Проаналізовано перспективність вирощування сортів айстри китайської (Callistepsus chinensis) на об'єктах озеленення Вінниччини. Зазначено про зростання попиту на нові сорти різних груп айстри однорічної у декоративному садівництві та необхідність створення декоративних сортів цієї культури, стійких до хвороб та адаптованих до умов навколишнього середовища. Вперше досліджено біоморфологічні особливості айстри китайської (Callistepsus chinensis), способи розмноження та визначено найперспективніші культивари для їх вирощування в умовах Вінниччини та для подальшого їх використання в ландшафтному озелененні різних об'єктів. Створено та уніфіковано колекцію сортів різних груп айстри китайської на території колекційної ділянки Вінницького національного аграрного університету. Враховуючи високі декоративні якості досліджуваних сортів та господарськобіологічні якості, всі сорти оцінено як добре адаптовані до едафо-кліматичних умов Поділля і рекомендовано як об'єкти для збагачення асортименту рослин для озеленення, колекційних та експозиційних фондів і селекційної діяльності. Різноманітність забарвлення та форм суцвіття, різні форми та висота куща дають змогу широко використовувати калістефус китайський (Callistephus chinensis) для створення поодиноких лінійних посадок, групових посадок, для влаштування міксбордерів $\mathrm{i}$ рабаток, на кам'янистих ділянках ландшафту і в бордюрах, для створення груп і клумб.

Ключові слова: біоморфологічні особливості; інтродукція; період цвітіння; декоративні якості; культивари.

\footnotetext{
${ }^{1}$ Тернопольский областной коммунальный институт последипломного педагогического образования, г. Тернополь, Украина ${ }_{2}^{2}$ Винницкий национальный аграрный университет, г. Винница, Украина
}

\section{ПЕРСПЕКТИВНОСТЬ ВЫРАЩИВАНИЯ И ИСПОЛЬЗОВАНИЯ CALLISTEPHUS CHINENSIS В} ОЗЕЛЕНЕНИИ ЗОНЫ ПОДОЛЬЯ

Одним из приоритетных в интродукционной работе цветочно-декоративных растений, как в Украине, так и во всем миpe, является астра однолетняя, или калистефус китайский (Callistepsus chinensis (L.) Nees). Отечественные и зарубежные ученые разнопланово занимаются изучением данного растения. Большинство работ, опубликованных в течение последних десятилетий, посвящены изучению и поиску наиболее благоприятных агротехнических приемов для выращивания астры в различных условиях. Проанализирована перспективность выращивания сортов астры китайской (Callistepsus chinensis) на объектах озеленения Винницкой области. Отмечено о росте спроса на новые сорта различных групп астры однолетней в декоративном садоводстве и необходимости создания декоративных сортов этой культуры, устойчивых к болезням и адаптированных к условиям окружающей среды. Впервые исследованы биоморфологические особенности астры китайской (Callistepsus chinensis), способы размножения и определены наиболее перспективные культивары для их выращивания в условиях Винниччины для дальнейшего их использования в ландшафтном озеленении различных объектов. Создана и унифицирована коллекция сортов различных групп астры китайской на территории коллекционного участка Винницкого национального аграрного университета. Учитывая высокие декоративные качества исследуемых сортов и хозяйственно-биологические качества, все сорта оценены как хорошо адаптированные к эдафо-климатическим условиям Подолья и рекомендованы в качестве объектов для обогащения ассортимента растений для озеленения, коллекционных и экспозиционных фондов и селекционной деятельности. Разнообразие окраски и форм соцветия, различные формы и высота куста дают возможность широко использовать калистефус китайский (Callistephus chinensis) при создании отдельных линейных посадок, групповых посадок, для устройства миксбордеров и рабаток, на каменистых участках ландшафта и в бордюрах, для создания групп и клумб.

Ключевые слова: биоморфологические особенности; интродукция; период цветения; декоративные качества; культивары. 


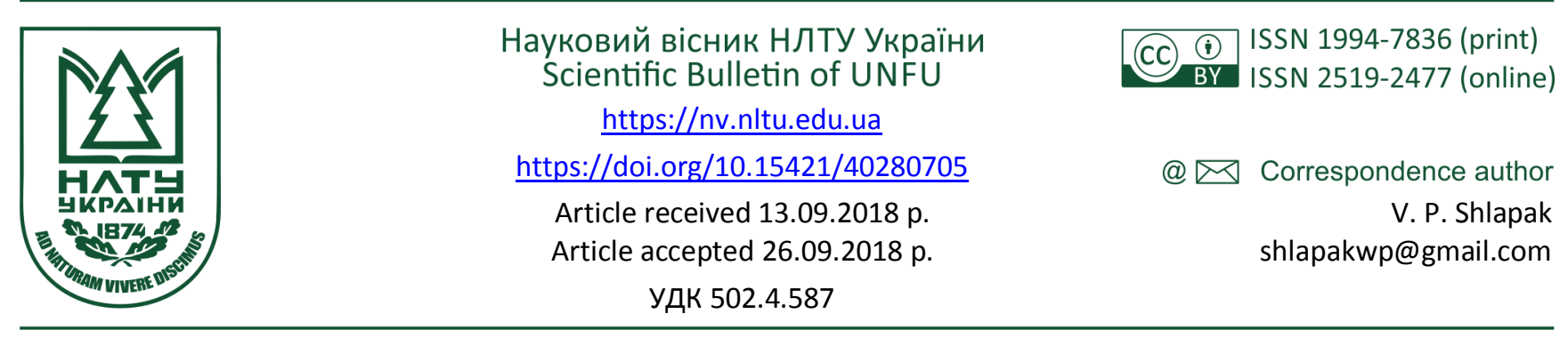

В. П. Шлапак', Н. П. Шиак', Г. П. Леонтяк², С. А. Коваль', О. Ю. Марно-Куца ${ }^{1}$

${ }^{l}$ Уманський національний університет садівництвва, м. Умань, Украӥна

${ }^{2}$ Національний природний парк "Кармелюкове Поділля", смт Чечельник, Украӥна

\title{
ДОСЛІДЖЕННЯ ПРОЦЕСІВ РОЗКЛАДАННЯ ПІДСТИЛКИ У ПРИРОДНИХ ДІБРОВАХ ПОДІЛЛЯ
}

\begin{abstract}
Проведено порівняння морфологічних характеристик та швидкості розкладання підстилки в різних за складом природних деревостанах. Розраховано опадо-підстилковий коефіцієнт (ОПК) або індекс інтенсивності біологічного кругообігу для всіх дослідних насаджень природних лісів Національного природного парку "Кармелюкове Поділля". Визначено сезонне зменшення маси підстилки. Встановлено, що показник ОПК залежить від складу деревостану, типу лісу, рельєфу та погодних умов. У насадженнях із перевагою опаду дуба звичайного спостережено накопичення значної маси та потужності підстилки. Виявлено вплив опаду береки і липи на швидкість розкладання підстилки в лісах природного походження. Рекомендовано вводити ці породи в культури дуба звичайного. Встановлено, що формування повітряно-гідрологічного режиму верхніх шарів грунту залежить від типу деревостану. Найбільш сприятливою для процесів грунтоутворення є грудкувато-листова структура, яку формує опад липи, береки та граба. Опад дуба розкладається найповільніше. Швидкість розкладання підстилки залежить від умов місцезростання та хімічного складу опаду. Середній показник опадо-підстилкового коефіцієнта становить для природних лісів 1,0-1,7. Визначений опадо-підстилковий коефіцієнт підтверджує вагомий вплив опаду липи й береки на мінералізацію підстилки за 2-3 роки. Тому в лісові культури дуба звичайного рекомендовано введення липи й береки, що сприятиме формуванню високопродуктивних подільських дібров.
\end{abstract}

Ключові слова: опадо-підстилковий коефіцієнт; лісова підстилка; опад; процес розкладання; типи дібров.

Вступ. Найважливішим екологічним чинником, що визначає можливість існування лісу є грунт. Від генетичного типу, механічного складу та інших властивостей грунту залежить породний склад лісу, а збалансоване надходження елементів живлення забезпечує оптимальний ріст деревних рослин. Грунти природних лісів відзначаються різним біологічним кругообігом, що сприяє нагромадженню поживних речовин. Вивчення питань малого біологічного кругообігу не $є$ новим. Найбільш значні й досконалі дослідження з питань малого біологічного кругообігу, а саме в ланці споживання хімічних елементів, виконано в МГУ під керівництвом Н. П. Ремезова (1961), П. С. Погребняка (1993), де в різних вікових категоріях сосняків вивчено щорічне споживання елементів живлення та повернення їх з опадом. Досліджували залежності між грунтом та фітоценозом у своїх працях такі вчені: А. А. Дубіна (1972), Н. Г. Ремезова (1961), А. П. Травлєєва (1972), Н. М. Цвєткова (1992). Органічний опад є основним матеріалом для утворення лісової підстилки і гумусу, однією із найважливіших ланок біологічного обміну речовин між лісом і грунтом. У наукових працях В. Р. Вільямса, Г. Ф. Морозова, С. В. Зонна, М. О. Ткаченка, як вказу- ють, посилаючись на них, М. І. Гордієнко, В. П. Шлапак, А. Ф. Гойчук, В. О. Рибак, В. М. Маурер, Н. М. Гордієнко, С. Б. Ковалевський (2002), висвітлено вплив лісового опаду на накопичення підстилки, характер грунтоутворення, ріст і продуктивність деревостанів, грунтозахисні властивості. На цій основі було започатковано балансовий метод оцінювання біологічного кругообігу за показниками: "взято - утримано - повернено". Згодом фундаментальні роботи Л. С. Родіна, Н. П. Ремезова і Н. І. Базилевича (1968) значною мірою поглибили знання про біологічний кругообіг у різних кліматичних зонах із різними рослинними асоціаціями, зокрема і в лісах Поділля.

Для визначення динаміки нагромадження і розкладання лісового опаду і підстилки в Пристепових культуpax сосни М. І. Гордієнко, В. П. Шлапак (1998) визначали масу лісової підстилки, річного опаду й опадо-підстилкові коефіцієнти в чистих і 3 домішкою дуба (1520 \%) соснових культурах 19-, 55- і 100-річного віку. Автори зробили висновок, що великих відхилень за масою річного опаду і лісової підстилки в насаджень однакового віку й складу не виявлено. Однак домішка дуба в складі культур сосни підвищує інтенсивність розкладан-

\section{Інформація про авторів:}

Шлапак Володимир Петрович, д-р с.-г. наук, професор, завідувач кафедри лісового господарства. Email: shlapakwp@gmail.com Шпак Ніна Петрівна, аспірант, кафедра лісового господарства. Email: karmelukove_podilla@ukr.net

Леонтяк Григорій Прокопович, д-р с.-г. наук, професор, завідувач кафедри садово-паркового господарства.

Email: leontyar_grisha@ukr.net

Коваль Сергій Анатолійович, канд. с.-г. наук, доцент, кафедра лісового господарства. Email: sergiy.koval24@ukr.net

Марно-Куца Олена Юріївна, канд. с.-г. наук, ст. викладач, кафедра лісового господарства. Email: leonora.marno@gmail.com Цитування за ДСту: Шлапак В. П., Шпак Н. П., Леонтяк Г. П., Коваль С. А., Марно-Куца О. Ю. Дослідження процесів розкладання підстилки у природних дібровах Поділля. Науковий вісник НЛту України. 2018, т. 28, № 7. С. 27-30.

Citation APA: Shlapak, V. P., Shpak, N. P., Leontyak, G. P., Koval, S. A., \& Marno-Kutsa, E. Yu. (2018). Research of litter decomposition processes in natural oak forests of Podillya. Scientific Bulletin of UNFU, 28(7), 27-30. https://doi.org/10.15421/40280705 
ня лісової підстилки. Як встановили В. П. Шлапак, I. I. Логвіненко (1999), величина опадо-підстилкового коефіцієнта в культурах різного віку дає уявлення про інтенсивність накопичення та розкладу лісової підстилки.

У нещодавно створеному Національному природному парку "Кармелюкове Поділля" протягом 20162017 pp. були проведені дослідження особливостей трансформації органічної речовини підстилки у природних біоценозах в умовах Південного Поділля 3 метою їх порівняння та виявлення відмінностей.

Як зазначив П. С. Погребняк (1993), Поділля охоплює найдальшу західну частину українського Лісостепу, що відрізняється від інших лісостепових районів значним піднесенням абсолютних височин поверхні, помірними температурними коливаннями, майже суцільним пануванням лісових грунтів. Чечельницьке лісництво (Вінницька обл.), на базі якого створено НПП "Кармелюкове Поділля", належить до Наддністрянського лісівничого району, південно-східного підрайону. Особливу цінність Національного природного парку "Кармелюкове Поділля" становлять лісові площі, де переважають дубово-грабові діброви природного насіннєвого походження, деревостани яких утворюють два види дуба: Quercus robur (L.) Willd i Quercus petraea Liebl. $з$ участю Sorbus torminalis (L.) Crantz. На типологічний склад лісів тут впливають експозиційні схи- ли, розчленовані ярами. На верхній частині схилів зустрічаємо абсолютне панування дуба скельного, у нижніх частинах схилів і ярках виявлено відсутність дуба скельного й панування дуба звичайного. Тут сформовані сірі опідзолені грунти та чорноземи опідзолені.

Проблема підвищення продуктивності та біологічної стійкості дібров Південного Поділля була і залишається надзвичайно важливою в нинішній екологічній ситуації. Незважаючи на значну кількість наукових розробок, вивчення питань зв'язку біологічного кругообігу поживних речовин між грунтом і деревостаном у сучасних екологічних умовах залишається актуальним.

Метою дослідження було визначення опадо-підстилкового коефіцієнта (ОПК) або індексу інтенсивності біологічного кругообігу для природних і штучних лісів Національного природного парку "Кармелюкове Поділля" та встановлення залежності цього показника від різних чинників.

Обговорення отриманих результатів дослідження. У лісових масивах парку закладено шість пробних площ, по 0,25 га кожна. Вік насаджень становить 65-90 років, повнота 0,6-0,8, 3 перевагою III і IV категорій дерев (за Крафтом). Підстилку відбирали у весняний, літній і осінній сезони $з$ десятикратною повторністю. Зважування та опис проб здійснювали за "Програмою і методикою біогеоценологічних досліджень" (1974) (табл. 1).

Табл. 1. Характеристика дослідних насаджень природного походження

\begin{tabular}{|c|c|c|l|}
\hline Склад насаджень & $\begin{array}{c}\text { Вік } \\
\text { деревостану }\end{array}$ & Місце зростання & \multicolumn{1}{|c|}{ Трав'яний покрив } \\
\hline 8Дз2Лпд+Яз+Клг & 80 & схил південної експозиції 8 & $\begin{array}{l}\text { осока парвська, зубниця бульбиста, цибуля ведмежа, } \\
\text { маренка пахуча }\end{array}$ \\
\hline 6Дз2Яз2Гз+Клг+Бер & 65 & $\begin{array}{c}\text { схил північно-західної експози- } \\
\text { ції 5॰, горбистий з ярами }\end{array}$ & $\begin{array}{l}\text { фiалка лісова, підмаренник весняний, зірочник ланце- } \\
\text { то-листий }\end{array}$ \\
\hline 9Дз1Бер+Гз & 90 & плато & $\begin{array}{l}\text { осока волосиста, чина весняна, купина широколиста, } \\
\text { копитняк європейський }\end{array}$ \\
\hline 7Дз2Гз1Бер & 80 & схил північної експозиції 7 & $\begin{array}{l}\text { плющ (покриття 20 \%), підмаренник чіпкий, осока во- } \\
\text { лосиста і парвська }\end{array}$ \\
\hline 6Дз4Гз+Бер & 75 & плато & осока парвська, цибуля ведмежа, конвалія травнева \\
\hline 6Дз2Яз1Гз1Лпд+Клг+Бер & 70 & плато & $\begin{array}{l}\text { цибуля ведмежа, конвалія травнева, чина весняна, ко- } \\
\text { питняк європейський }\end{array}$ \\
\hline
\end{tabular}

До однієї з головних характеристик біологічного кругообігу можна віднести його інтенсивність. Показником, який дає уявлення про інтенсивність, можна вважати коефіцієнт утилізації органічної речовини - опадопідстилковий коефіцієнт (ОПК) (М. І. Гордієнко, В. П. Шлапак, А. Ф. Гойчук, В. О. Рибак, В. М. Маурер, Н. М. Гордієнко, С. Б. Ковалевський, 2002, В. І. Парпан, 1977, І. В. Царик， 1977, М. І. Гордієнко, В.П.Шлапак, 1998, В. П. Шлапак, І. І. Логвіненко, 1999). Опадо-підстилковий коефіцієнт визначали як відношення кількості нерозкладеної підстилки до кількості опаду зеленої маси. Він дає можливість із певною вірогідність виміряти швидкість біокругообігу речовин у конкретному біогеоценозі, характеризує відношення запасів підстилки до запасів опаду зеленої маси. Термін, який ввів німецький учений Ебермайер у 1953 р., вживають для оцінювання швидкості розкладу мертвих органічних залишків. Цей показник об'єктивно оцінює початкову швидкість деструкції та мінералізації свіжо відмерлої фітомаси.

Швидкість розкладу органічних залишків залежить від сукупності чинників, які можна об'єднати у три групи. Перша група характеризує якісний склад рослинного опаду. Вона включає видовий і фракційний склад опаду, вік, особливості хімічного складу рослин у різних умовах існування, сезонні зміни та ін. До другої групи можна віднести діяльність живих організмів, які розкладають майже всі органічні речовини. Серед них особливої уваги заслуговують бактерії, гриби, грунтові безхребетні та ін. Третя група чинників показує вплив умов середовища, зокрема: температури, вологості та ін. Усі перелічені чинники впливають разом і часто зумовлюють один одного.

Тип деревостану також відіграє визначальну роль у структурі налягання листових пластин. Такі породи, як: граб, липа, берека, ясен, формують пухку підстилку, яка добре пропускає повітря та вологу, а також сприяє росту молодих паростків. Щільна підстилка дуба має клейончасту структуру. Така підстилка набагато гірше пропускає повітря до верхніх горизонтів грунту, погано поглинає вологу, затримуючи на своїй поверхні, що сприяє випаровуванню води і зменшенню надходжень iii до грунту. Молодим пагонам важко пробитися крізь таку підстилку, а відсутність вологи призводить до їх всихання у літній період.

Накопичена маса $є$ одним із важливих показників швидкості розкладання підстилки. Чим інтенсивніше буде відбуватися процес деструкції органічної речовини, тим менша маса підстилки буде на кінець сезону вегетації. Дослідженнями встановлено, що в осінній період ці показники дорівнювали 6,0-11,6 т/га. Дані для кожного насадження наведено в табл. 2. 
Табл. 2. Накопичення опаду та ОПК для природних насаджень

\begin{tabular}{|c|c|c|c|c|c|c|c|c|c|c|c|c|c|}
\hline \multirow[b]{2}{*}{ Діброва } & \multirow{2}{*}{$\begin{array}{l}\text { Квартал } \\
\text { / виділ }\end{array}$} & \multirow[b]{2}{*}{ Склад деревостану } & \multirow{2}{*}{$\begin{array}{l}\text { Вік, } \\
\text { років }\end{array}$} & \multirow{2}{*}{$\begin{array}{c}\text { Повно- } \\
\text { та }\end{array}$} & \multicolumn{7}{|c|}{ Кількість опаду за породами, \% } & \multirow{2}{*}{$\begin{array}{c}\text { Кількість } \\
\text { підстил- } \\
\text { ки, \% }\end{array}$} & \multirow[b]{2}{*}{ ОПК } \\
\hline & & & & & Дз & $\Gamma 3$ & Яз & Лпд & $\begin{array}{l}\text { Клг } \\
\text { Клп } \\
\end{array}$ & Бер & Інші & & \\
\hline Дубово-липова & $87 / 1$ & $\begin{array}{r}8 Д_{32 J} \\
+Я_{3}+K_{J}\end{array}$ & 80 & 0,7 & 35,7 & 15,0 & 4,7 & 44,6 & - & - & - & 50,1 & 1 \\
\hline $\begin{array}{c}\text { Дубово-ясенево- } \\
\text { грабова }\end{array}$ & $0 / 1$ & 6Дз2Яз1Гз+Клг+Бер & 65 & 0,7 & 51,7 & 20,2 & 21,5 & - & 2,7 & 3,9 & 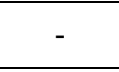 & 56,8 & 1,3 \\
\hline Дубово-берекова & $86 / 7$ & 9Дз1Бер+Гз & 90 & 0,8 & 43,2 & 14,4 & - & - & 2,6 & 39,8 & $\begin{array}{c}\text { свидина } \\
2,8\end{array}$ & 66,1 & 1,5 \\
\hline $\begin{array}{r}\text { Дубово-гра } \\
\text { береко } \\
\end{array}$ & $81 / 1$ & $\begin{array}{l}\text { 7Дз2Гз } \\
\text { 1Бер }\end{array}$ & 80 & 0,7 & 60,8 & 14,5 & - & - & - & 19,4 & $\begin{array}{c}\text { кизил } \\
5,35 \\
\end{array}$ & 72,2 & 1,65 \\
\hline Дубов & & 6 Дз4Гз + Бер & 75 & 0,6 & 70,1 & 13,2 & - & - & - & 16,7 & - & 74,8 & 1,6 \\
\hline Дубово-ясенева & $66 / 8$ & 6Дз2Яз1Гз1Лпд+Клг+Бер & 70 & 0,7 & 65,0 & 8,4 & 7,2 & 2,4 & 10,1 & 8,2 & - & 77,6 & 1,7 \\
\hline
\end{tabular}

Якщо порівняти дані ОПК, то можна відзначити, що, окрім умов місцезростання, на розкладання підстилки впливає хімічний склад опаду. Підстилка з перевагою дуба містить багато дубильних речовин, які знижують роботу мікробіоти, тому в чистих дубових насадженнях знаходиться 4-5-річний запас щорічного опаду, що відповідає загальмованому типу кругообігу. Взявши до уваги опад липи і береки, можна стверджувати, що він прискорює розкладання опаду дуба, а домішка опаду клена з ясенем сповільнюють цей процес.

Розкладання підстилки відбувається в теплий період року та проявляється у зменшенні їі маси щодо початкової. Процес розкладання підстилки, з якої формується м'який перегній, характеризується певною швидкістю. Використавши дані розкладання підстилки в різних деревостанах, можна порівняти швидкість ії розкладання на основі встановлених відсоткових частин мінералізованих мас підстилки за вегетаційний період (рисунок).

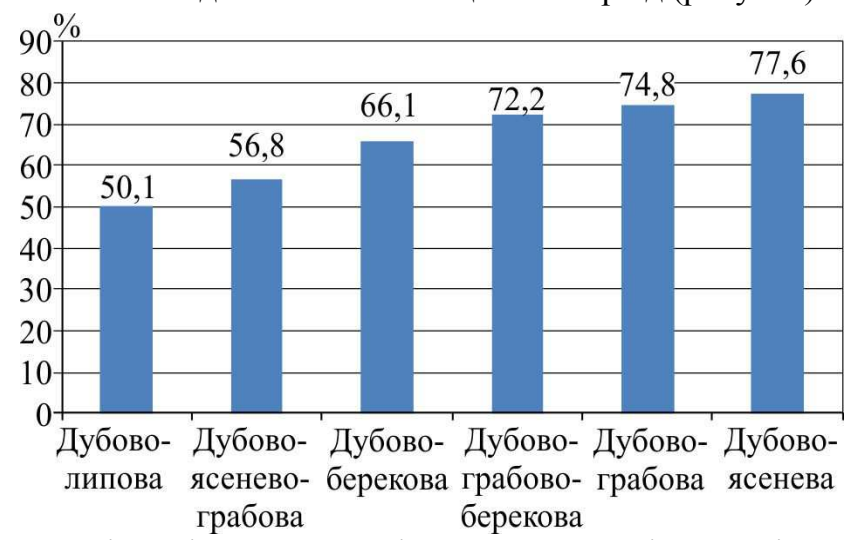

Рис. Мінералізована частка підстилки за вегетаційний період

Як видно з рисунка, найбільша маса підстилки за вегетаційний період мінералізувалася у дубово-липовій діброві. Менша маса підстилки мінералізувалася у насадженнях, в яких у ній переважає листя дуба. Виявлено позитивний вплив на мінералізацію підстилки наявності в іiї складі значної кількості листя береки.

\section{Висновки:}

1. Формування повітряно-гідрологічного режиму верхніх шарів грунту залежить від типу деревостану. Найбільш сприятливою для процесів грунтоутворення $є$ грудкувато-листова структура, яку формує опад липи, береки та граба. Опад дуба розкладається найповільніше.

2. Швидкість розкладання підстилки залежить від умов місцезростання та хімічного складу опаду. Середній показник опадо-підстилкового коефіцієнта становить для природних лісів 1,0-1,7. Формування змішаних насаджень сприяє прискоренню процесу розкладання опаду дуба звичайного.
3. Визначений опадо-підстилковий коефіцієнт підтверджує вагомий вплив опаду липи й береки на мінералізацію підстилки за 2-3 роки. Тому в лісові культури дуба звичайного рекомендуємо введення цих супутніх порід, що сприятиме формуванню високопродуктивних подільських дібров.

\section{Перелік використаних джерел}

Dubin, А. А. (1972). Forest litteras a component of natural forest biogeocenosis of the sout heast of Ukraine and the Moldovan garnets an forests. Abstract of Candidate Dissertation for Biology Sciences (03.02.07-Genetics). Donetsk, 17 p. [In Ukrainian].

Gordienko, M. I., \& Shlapak, V. P. (1998). The near steppe pine forests of Ukraine. Lviv: Prestige Inform, 265 p. [In Ukrainian].

Gordienko, M. I., Shlapak, V. P., Goichuk, A. F., Rybak, V. O., Maurer, V. M., Gordiyenko, N. M., \& Kovalevsky, S. B. (2002). Scots Pine (Pinus sylvestris L.) in Ukraine. Kyiv: Institute of Agricultural Economics, 872 p. [In Ukrainian].

Parpan, V. I. (1977). Litter, fores litter and biocorre lation of chemical elements in cultural forest biogeocenosis of the Lesser Polesye of the USS. Abstract of Candidate Dissertation for Biology Sciences (03.00.12 - Plant Physiology). Donetsk, 20 p. [In Ukrainian].

Pogrebnyak, P. S. (1993). Forest ecology and typology. Kyiv: Naukova Dumka, 495 p. [In Ukrainian].

Popova, N. V. (2007). Diagnostics of Ecosystem Stability by Intensity of Organic Substance Transformation Processes. Ecological systems and devices, 5, 3-5. [In Ukrainian].

Remezov, N. G. (1961). Decomposition of forest litter and circulation of elements in oak forests. Soil Science, 7, 1-12. [In Ukrainian].

Rodin, L. E., Remezov, N. P., \& Bazilevich, N. I. (1968). Methodological Instruction stothestudy of dynamics and biological cycleinphytocenoses. Leningrad. 143 p. [In Ukrainian].

Shlapak, V. P., \& Logvinenko, I. I. (1999). The Chyhyryn pine forest. Lviv: Prestige Inform, 110 p. [In Ukrainian].

Travleev, A. P. (1972). The interaction of vegetation with soilsin forest biogeocenoses of the present steppes of Ukraine and Moldova. Abstract of Doctoral Dissertation for Biology Sciences (06.03.01 Forest Crops and Phytomelioration). Dnipro. 49 p. [In Ukrainian].

Tsarik, I. V. (1977). Accumulation and decomposition of litterin biogeocenoses of the subalpine belt of the Carpathians. Abstract of Candidate Dissertation for Biology Sciences (03.02.07 - Genetics). Dnipro, 30 p. [In Ukrainian].

Tsvetkova, N. N. (1992). Peculiarities of migration of organo mineral substances and microelements in forest biogeocenosis of the Ukrainian steppe. Dnipro: DSU. 236 p. [In Ukrainian].

Vyshenska, I. G., Didukh, Ya. P., Skidanova, A. A., \& Alioshkina, U. M. (2007). Comparative study of the forest bedding energy storage of coniferous and deciduous phytocoenosis. Ukrainian botanical journal, 64(2), 177-194. [In Ukrainian].

Zhitska, N. V. (2011). Investigation of the connection between the rate of decomposition of little randash precipitation in natural forest biogeocenosis. Arboriculture and agroforestry, 119, 137. [In Ukrainian].

Zhitska, N. V. (2013). Environmental properties of litter forest biogeocenosis (near the outskirts of the Cherkasy Region). Kyiv, 20 p. [In Ukrainian]. 


\section{В. П. Шлапак ${ }^{1}$, Н. П. Шпак ${ }^{2}$, Г. П. Леонтяк ${ }^{2}$, С. А. Коваль ${ }^{1}$, Е. Ю. Марно-Куца \\ ${ }^{l}$ Уманский национальный университет садоводства, г. Умань, Украина \\ ${ }^{2}$ Национальный природный парк "Кармелюково Подолье", пгт Чечельник, Украина}

\section{ИССЛЕДОВАНИЕ ПРОЦЕССОВ РАЗЛОЖЕНИЯ ПОДСТИЛКИ}

В ЕСТЕСТВЕННЫХ ДУБРАВАХ ПОДОЛЬЯ

Проведено сравнение морфологических характеристик и скорости разложения подстилки в различных по составу природных древостоях. Рассчитан опадо-подстилочный коэффициент (ОПК) или индекс интенсивности биологического круговорота для всех исследовательских (опытных) насаждений природных лесов Национального природного парка "Кармелюково Подолье". Определено сезонное уменьшение массы подстилки. Интервал средних показателей ОПК составил для природных лесов 1,0-1,7. Установлено, что показатель ОПК зависит от состава древостоя, типа леса, рельефа и погодных условий. В насаждениях с преобладанием опада дуба черешчатого имеет место накопление значительной массы и мощности подстилки. Выявлено влияние опада береки и липы на скорость разложения подстилки в лесах природного происхождения. Рекомендовано вводить эти породы в культуры дуба черешчатого. Установлено, что формирование воздушно-гидрологического режима верхних слоев почвы зависит от типа древостоя. Наиболее благоприятной для процессов почвообразования является комковато-листовая структура, которую формирует опад липы, береки и граба. Опад дуба разлагается медленнее. Установлено, что средний показатель опадо-подстилочного коэффициента составляет для природных лесов $1,0-1,7$. Определенный опадо-подстилочный коэффициент подтверждает значительное влияние опада липы и береки на минерализацию подстилки за 2-3 года. Поэтому в лесные культуры дуба черешчатого рекомендуем введение липы и береки, что будет благотворно влиять на формирование высокопродуктивных подольских дубрав.

Ключевые слова: опадо-подстилочный коэффициент; лесная подстилка; опад; процесс разложения; типы дубрав.

V. P. Shlapak ${ }^{1}$, N. P. Shpak' ${ }^{2}$, G. P. Leontyak ${ }^{2}$, S. A. Koval ${ }^{1}$, E. Yu. Marno-Kutsa ${ }^{1}$

${ }^{1}$ Uman National University of Horticulture, Uman, Ukraine

${ }^{2}$ National Park "Karmelyukove Podillya", Chechelnik, Ukraine

\section{RESEARCH OF LITTER DECOMPOSITION PROCESSES IN NATURAL OAK FORESTS OF PODILLYA}

The research compares morphological characteristics and speed of litter decomposition in natural oak forests that differ by their composition. Leaf fall litter rate (LLR) or index of intensity of biological rotation is calculated for all experimental natural forest plantations of Karmelyuk Podillya National Park. The seasonal litter reduction is identified. The mean value LLR interval for the natural forests is 1-1.7. It is concluded that this index depends on the composition of the woodland, the type of the forest, the lay of the land and the weather conditions. In the plantations with English oak (Quercus robur) prevalence the accumulation of massive powerful bedding takes place. The leaf fall of wild Service tree (Sorbus torminalis) and large-leaved Lime (Tilia platyphyllos) is determined to effect the speed of the bedding decomposition in the natural forests. The introduction of these species into the English oak plantations is recommended. The organic decomposition, which is the main material for the formation of forest litter and humus and, at the same time, one of the most important parts of biological forest and soil metabolism, is explored. The formation of the airhydrological regime of the upper soil layers is revealed to depend on the type of the woodland. The determined sediment-bedding factor confirms the significant influence of lime and bereach leaf fall on the 2-3 year mineralization of litter. Therefore, in the forest cultures of English oak, the authors recommend introduction of wild Service tree and large-leaved Lime, which will contribute to the formation of highly productive Podilsky groves. To determine the dynamics of accumulation and decomposition of forest precipitates and litter, the authors determined the mass of forest litter, annual precipitation and sediment-bedding coefficients and on this basis concluded that large deviations by weight of annual precipitation and forest litter in plantations of the same age and composition were not found. However, the admixture of English oak in the composition of mixed cultures increases the intensity of decomposition of forest litter.

Keywords: leaf fall litter rate; forest litter; leaf fall; decomposition process; types of oak forest. 